Journal of Anatolian Environmental and Animal Sciences

(Anadolu Çevre ve Hayvancılık Bilimleri Dergisi)

DOI: https://doi.org/10.35229/jaes.828969

\title{
Effects of Whey Protein on Biochemical Composition of Rainbow Trout
}

\section{(Oncorhynchus mykiss)}

\author{
Mikail ÖZCAN ${ }^{*}$ Ünal İSPİR ${ }^{2} \quad$ Ayşegül ŞAHİN $^{3}$ \\ ${ }^{1 *}$ Kahramanmaras Sütcü Imam University, Agriculture Faculty, Department of Fisheries, Kahramanmaraş, Turkey \\ ${ }^{2}$ Malatya Turgut Ozal University, Doğanşehir Vahap Küçük Vocational School, Department of Aquaculture, Malatya, Turkey \\ ${ }^{3}$ Elazig Directoriate Fisheries Research Station, Elazig-Turkey
}

How to cite: Özcan, M., İspir, Ü. \& Şahin, A. (2021). Effects of Whey Protein on Biochemical Composition of Rainbow Trout (Oncorhynchus mykiss). J. Anatolian Env. and Anim. Sciences, 6(2), 170-173.

Atıf yapmak için:Özcan, M., İspir, Ü.\& Şahin, A. (2021). Gökkuşağı Alabalığının (Oncorhynchus mykiss) Biyokimyasal Bileşimi Üzerine Peynir Alt Suyu Proteinin Etkileri. Anadolu Çev. ve Hay. Dergisi, 6(2), 170-173.

(iD): https://orcid.org/0000-0001-9032-0697

(iD): https://orcid.org/0000-0002-2077-0219

(iD): https://orcid.org/0000-0002-6609-2687

*Correspondingauthor's:

Mikail ÖZCAN

Kahramanmaras Sütcü Imam University,

Agriculture Faculty, Department of Fisheries,

Kahramanmaraş, Turkey

凶: mikailozcan@ksu.edu.tr

\begin{abstract}
The aim of this study was to investigate the impact of whey protein on several biochemical parameters in the tissues of rainbow trout. The fish utilized in this study were an average weight of 40-45 g. Rainbow trout were fed diets containing four doses of whey protein $(0$; $0.5,1.0$ and $1.5 \%$ ) for 42 days. At the end experiment, spleen, a liver, muscle and kidney tissue was taken from fish and carbohydrate, lipid and protein levels were determined. The value of this parameters (total protein, total lipid and carbohydrate) was essentially affected for fish fed the diet with $1.0 \%$ and $1.5 \%$ included whey protein. Carbohydrate level in the all tissues was not affected by dietary levels of whey protein. Lipid levels of fish fed diets with $1.5 \%$ added whey protein was essentially higher than that of fish fed the control diet. The use of alternative protein sources such as whey protein can be an option.
\end{abstract}

Keywords: Carbohydrate content, lipid level, protein, rainbow trout, whey protein.

\section{Gökkuşağı Alabalığının (Oncorhynchus mykiss) Biyokimyasal Bileşimi Üzerine Peynir Alt Suyu Proteinin Etkileri}

\section{*Sorumlu yazar:}

Mikail ÖZCAN

Kahramanmaraș Sütçü İmam Üniversitesi,

Ziraat Fakültesi, Su Ürünleri Bölümü,

Kahramanmaraş, Türkiye

\: mikailozcan@ksu.edu.tr
Öz: Bu çalıșmanın amacı bazı biyokimyasal yöntemler kullanılarak Gökkuşağı Alabalığı dokularına peynir alt suyu proteinin etkisi incelenmiştir. Çalışmada ortalama ağırlıkları 40-45 gr olan balıklar kullanılmıștır. Gökkuşağı alabalığı, 42 gün boyunca dört doz peynir alt suyu protein $(\% 0 ; 0,5,1,0$ ve 1,5$)$ içeren yemle beslenmiştir. Deney sonunda balıklardan karaciğer, dalak, böbrek ve kas dokuları alınarak protein, karbonhidrat ve lipid seviyeleri belirlenmiştir. Bu parametrelerin (total protein, total lipid ve total karbonhidrat) değeri, $\% 1,0$ ve $\% 1,5$ peynir alt suyu protein eklenen yemlerle beslenen balıklarda önemli ölçüde etkilenmiştir. Tüm dokulardaki karbonhidrat seviyesi, yemdeki peynir alt suyu protein oranlarında etkilenmemiştir. \%1,5 peynir alt suyu protein oranı içeren yemlerle beslenen balıkların lipit seviyeleri, control yemiyle beslenen balıklara gore önemli ölçüde artmıştır. Peynir alt suyu protein gibi alternative protein kaynaklarının kullanılması için bir seçenek olabilir.

Anahtar kelimeler: Gökkușağı alabalığı, karbonhidrat içerĭği, lipid seviyesi, protein, peynir alt suyu proteini. 


\section{INTRODUCTION}

Production of rainbow trout (Oncorhynchus mykiss) has become the largest aquaculture enterprise in the Turkey (Doğan, 2010). In rainbow trout farming, protein is an expensive ingredient in fish feeds and constitutes the important cost of the feed. Fish breeders have tried to reduce the cost of feed by using cheap vegetable proteins instead of expensive animal proteins (Rana et al., 2009).

Whey is spin-off casein, cheese and quark manufacture (Maswaure \& Mandisodza, 1995; De Wit, 1998). Whey is obtained from the sedimentation of casein in milk or skimmed milk followed by mechanical segregation from fat and casein (Codex Alimentarius, 2006). It contains most of the minerals, lactose and consists up to $96 \%$ of water, and water-soluble protein, which are left from casein processing, quark or cheese (Cinq-Mars et al., 1986). The protein parts of whey occur of nearly at a ratio of 70:28, lacto-albumin and lacto-globulin (Mahan, 1992; De Wit, 1998). Lacto-albumin is harderdenaturated during the drying process than lacto-globulin. For this reason, it is usually considered to be a protein component with a superior biological value (Mahan, 1992).

Whey protein contains a large number of essential amino acids and takes charge an significant role in protein synthesis, and carbohydrate metabolism necessary to provide energy (Yoshizawa, 2004). On the biochemical parameters of fish are effective various factors, out of which the species, age, environmental condition, nutrition and maturation are very important (Campbell, 2004). Absorption ratio of amino acids from the intestine from whey protein or casein based diets affects the protein synthesis within the oxidation of amino acids and whole body protein catabolism (Boirie et al., 1997). There was no published report on biochemical effect of whey protein on rainbow trout. Based on the observations from literature survey, it was envisaged to study the various biochemical effect of the ethanol extract of whey protein in rainbow trout, Oncorhynchus mykiss.

\section{MATERIAL AND METHOD}

Rainbow trout ( $45 \pm 0.03 \mathrm{~g})$ was supplied from a commercial fish farm (Kahramanmaras- Turkey). The fish were kept in a $225 \mathrm{~L}$ fiberglass tank. Prior to each experiment the fish were transferred tank containing aerated well water and acclimatized for a minimum for 2 weeks. Fish use and experimental protocol were approved by KSÜZİRHADYEK Animal Ethics Committee (Protocol number: 2017/01).

Fish were fed daily at $2 \%$ of fish weight with a commercial fish food $(40 \%$ protein, $11 \%$ fat, $10.1 \%$ crudeash, $1.3 \%$ crude fiber, $2.4 \%$ calcium, $1.5 \%$ phosphorus, $0.3 \%$ sodium, $0.6 \mathrm{NM}$ granular fry feed containing).

Whey was prepared from cow milk acquired from a market in Kahramanmaras, Turkey, using rennet coagulation according to the method of Ha et al. (2014), as described in Kishawy et al. (2018). The whey was used to prepare whey protein concentrates, according to Nishanthi et al. (2017).

Fish were stocked in 4 groups (50 fish/per group) in the tanks. Light/dark cycle was 12L:12D. During the experiment, $\mathrm{pH}$, average dissolved oxygen and water temperature were $7.8 \pm 0.09,8.5 \pm 0.14 \mathrm{ppm}$ and $12 \pm 0.22^{\circ} \mathrm{C}$, respectively.

After two weeks of acclimation to the condition, to study the biochemical mechanisms, fish were allocated into four tanks (50 fish/tank) and fed diets containing three doses of whey protein $(0 ; 0.5,1.0$ and $1.5 \%)$. Also control group only was feed with a commercial feed. Fish were fed to apparent satiation twice daily (between 08:00-09:00 and 16:00-17:00) for 42 days.

The experiment was conducted in two replications. This study were used total of 400 fish with 50 fish in each group. After the test period, the fish were anesthetized with an anesthetic substance $(50 \mathrm{mg} / \mathrm{L}$, benzocaine) (Hseu et al., 1998) and the whole body was kept in aluminum foils at $-20{ }^{\circ} \mathrm{C}$ until biochemical processes were performed.

The total protein, total fat, and carbohydrate percent of fish tissues (liver, spleen, kidney and muscle) were measured using standard methods of Association of Official Analytical Chemists (AOAC, 1990).

Parametric tests were used to reveal the differences between groups. Differences between mean values were compared using one-way analysis of variance (ANOVA) and Duncan tests. All data are given as mean \pm standard error.

\section{RESULTS AND DISCUSSION}

This study was determine the effective concentrations of whey protein $(0 ; 0.5,1.0$ and $1.5 \%)$ on some biochemical parameters in muscle, liver, kidney and spleen of rainbow trout (Table 1).

Changes in protein levels in tissues of rainbow trout are shown in Fig. 1. Protein concentration of increased with increasing concentrations of dietary. In present study, total protein levelswas higher according to control group in the 1.0 and $1.5 \%$ whey protein group $(\mathrm{P}<0.05)$.

Muscle total lipid content was significantly higher in fish fed the diet with $1.5 \%$ of whey protein than those of the other experimental groups. No significant differences were observed among the values for fish fed dietary whey 
protein levels of $0.5 \%$. Liver lipid content was highest in fish fed the $1.5 \%$ whey protein supplemented diet (Fig. 2).

Tablo 1. Effect whey protein on total protein, lipid and carbohydrate content of rainbow trout.

\begin{tabular}{ccccc}
\hline Sample & Groups & $\begin{array}{c}\text { Total Protein } \\
(\mathbf{m g} / \mathbf{g})\end{array}$ & $\begin{array}{c}\text { Total Lipid } \\
(\mathbf{m g} / \mathbf{g})\end{array}$ & $\begin{array}{c}\text { Total Carbohydrate } \\
(\mathbf{\mu g} / \mathbf{g})\end{array}$ \\
\hline \multirow{4}{*}{ Muscle } & Control & $11.2 \pm 0.13$ & $88 \pm 0.3$ & $8.29 \pm 0.8$ \\
& $\mathbf{0 . 5 0 \%}$ & $10.98 \pm 0.14$ & $86 \pm 0.17$ & $7.99 \pm 0.11$ \\
& $\mathbf{1 . 0 0 \%}$ & $12.09 \pm 0.17$ & $91 \pm 0.11$ & $9.12 \pm 0.15$ \\
& $\mathbf{1 . 5 0 \%}$ & $12.79 \pm 0.22$ & $71 \pm 0.7$ & $10.06 \pm 0.45$ \\
& Control & $18.4 \pm 0.11$ & $31.56 \pm 0.33$ & $191.03 \pm 0.52$ \\
Liver & $\mathbf{0 . 5 0 \%}$ & $18.6 \pm 0.9^{\mathrm{a}}$ & $33.28 \pm 0.25$ & $178,42 \pm 0.37$ \\
& $\mathbf{1 . 0 0 \%}$ & $19.79 \pm 0.7^{\mathrm{b}}$ & $33.48 \pm 0.22$ & $197.13 \pm 0.26$ \\
& $\mathbf{1 . 5 0 \%}$ & $20.45 \pm 0.1$ & $32.89 \pm 0.29$ & $200.01 \pm 0.34$ \\
& $\mathbf{C o n t r o l}$ & $9.72 \pm 0.12$ & $16.88 \pm 0.18$ & $12.18 \pm 0.15$ \\
Kidney & $\mathbf{0 . 5 0 \%}$ & $9.98 \pm 0.8^{\mathrm{c}}$ & $16 \pm 0.3$ & $11.28 \pm 0.5$ \\
& $\mathbf{1 . 0 0 \%}$ & $10.51 \pm 0.6^{\mathrm{d}}$ & $16.25 \pm 0.44$ & $12.57 \pm 0.64$ \\
& $\mathbf{1 . 5 0 \%}$ & $11.28 \pm 0.3$ & $16.5 \pm 0.46$ & $12.41 \pm 0.21$ \\
& $\mathbf{C o n t r o l}$ & $8.8 \pm 0.14$ & $19.5 \pm 0.20$ & $9.19 \pm 0.27$ \\
Spleen & $\mathbf{0 . 5 0 \%}$ & $8.6 \pm 0.18$ & $19.25 \pm 0.37$ & $8.92 \pm 0.41$ \\
& $\mathbf{1 . 0 0 \%}$ & $8.79 \pm 0.10$ & $20.12 \pm 0.14$ & $9.93 \pm 0.22$ \\
& $\mathbf{1 . 5 0 \%}$ & $9.19 \pm 0.13$ & $18.88 \pm 0.33$ & $11.03 \pm 0.41$ \\
\hline
\end{tabular}

Dietary treatments did not significantly affect carbohydrate values of all tissues (Fig. 3). The carbohydratelevels at low concentration were decreased from that in the control group $(\mathrm{P}>0.05)$. In experiment, when the addition of whey protein supplements to diets was increased to 1.0 and $1.5 \%$, carbohydrate level of fish was slightly, but not significantly $(\mathrm{P}>0.05)$, higher than those fish with the $0.5 \%$ levels of whey protein or the control diet.

In studies conducted in Motalebi \& Seyfzadeh (2011), was to investigate the effects of whey protein coating on the quality of common Kilka fish during frozen storage. As a result of the research, protein content showed an increase in covered samples compared with the control sample. In present study, changes in protein levels in tissues of rainbow trout are shown in Figure 1. Protein concentration of increased with increasing concentrations of dietary. Total protein levelswas higher according to control group in the 1.0 and $1.5 \%$ whey protein group $(\mathrm{P}<0.05)$. This may be due to the impact of a few protein compounds such as $\beta$-lactoglobine and $\alpha$-lactalbomine of this film (Shahidi \& Botta, 1990).

Concentration of lipid showed an increase in the covered samples compared with the control group (Motalebi \& Seyfzadeh, 2011). In this study, muscle total lipid content was importantly higher in fish fed the diet with $1.5 \%$ of whey protein than those of the other experimental groups. No important dissimilarity were observed between the values for fish fed dietary whey protein levels of $0.5 \%$. Liver lipid content was highest in fish fed the $1.5 \%$ whey protein supplemented diet (Figure 2 ). That is because of the presence of glycerides of milk lipid, lipo-proteins and phospho-lipids in whey protein. Oxidation of the lipid arising from the reaction of lipid with oxygen and its hydrolysis are affected by the activity of lipolytic enzymes (Deis, 2006; Min et al., 2006).

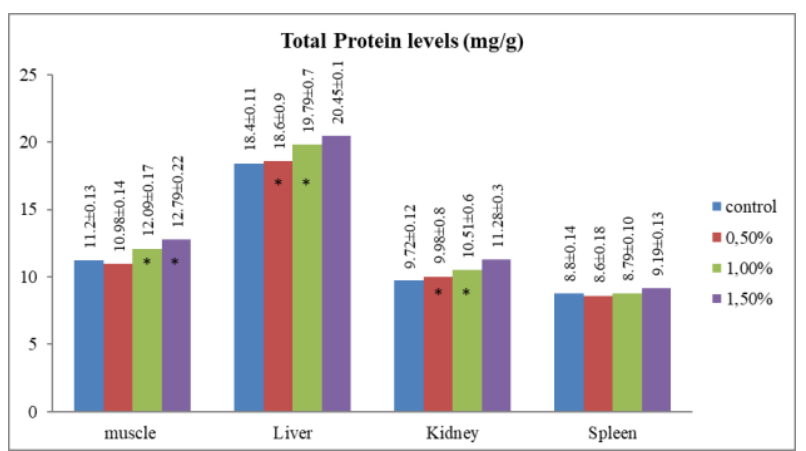

Figure 1. Total protein levels $(\mathrm{mg} / \mathrm{g})$ in the several tissues of rainbow trout.

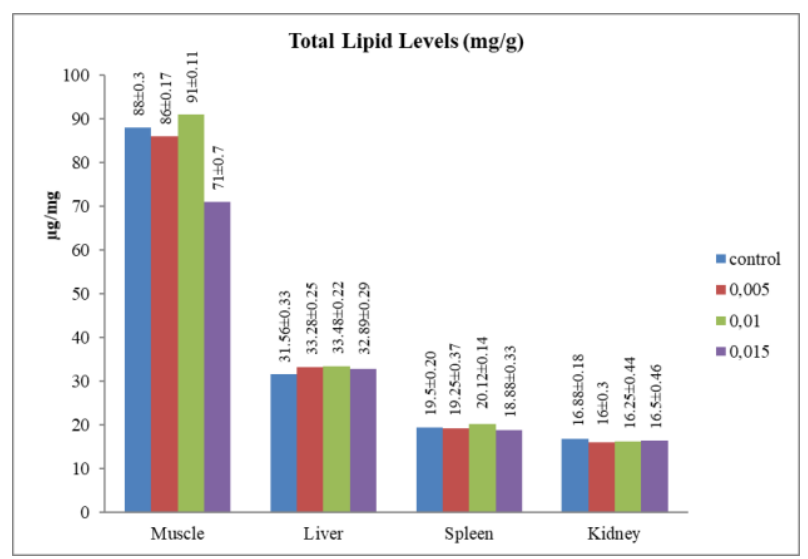

Figure 2. Total lipid levels $(\mathrm{mg} / \mathrm{g})$ in the several tissues of rainbow trout.

Carbohydrate used the most easily by fish is glucose and the only sugar in the blood. With the breakdown of glucose, the energy needed to maintain vital activities is provided (Hoşsu et al., 2001). Dietary treatments did not significantly affect carbohydrate values of all tissues (Figure 3). The carbohydrate levels at low concentration were decreased from that in the control group $(\mathrm{P}>0.05)$. In experiment, when the addition of whey protein supplements to diets was increased to 1.0 and $1.5 \%$, carbohydrate level of fish was slightly, but not significantly (P>0.05), higher than those fish with the $0.5 \%$ levels of whey protein or the control diet. Blood glucose is stored as glycogen in the liver of fish, and when the organism needs it, it is converted into glucose and given to the blood (Girgin Basusta, 2005).

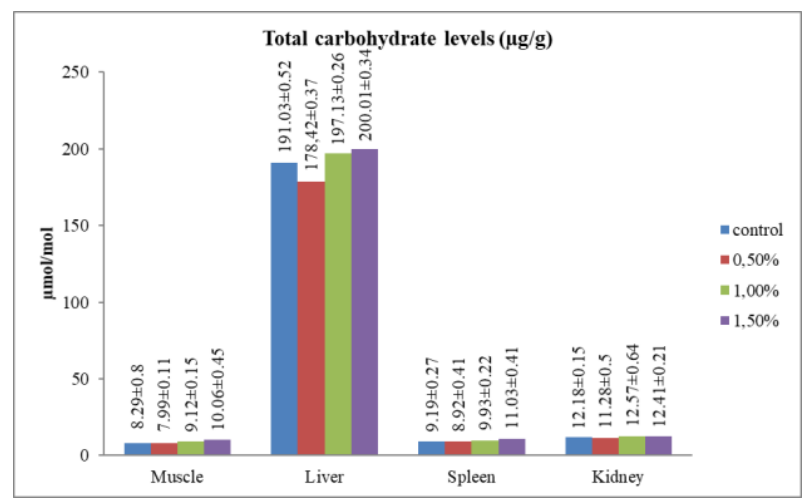

Figure 3. Carbohydrate levels $(\mu \mathrm{g} / \mathrm{g})$ in the several tissues of rainbow trout. 


\section{CONCLUSION}

The use of alternative protein sources such as whey protein can be an option. However, the level of anti nutritional factors has to be watched carefully. To prevent or reduce problems in fish, it is recommended to use feed with a low level of digestible protein. Results from the present study clearly demonstrated that a diet having $1.5 \%$ protein supplemented was found to be the optimum for positive effect biochemical parameters of rainbow trout. Further studies examining the mechanisms underlying the impacts of whey protein are needed. The information of this study will shed light on new researches in the future and contribute to the scientific literature.

\section{ACKNOWLEDGEMENTS}

This work was presented as a oral presentation at the International Symposium on Fisheries and Aquatic Science (FABA), 03 and 05 November 2016 in Antalya, Turkey.

\section{ETHICAL APPROVAL}

All animal studies were approved by the Animal Ethics Committee of Kahramanmaraş Sütçü Imam University, Faculty of Agriculture (KSÜZIRHADYEK) and Research Institute (Protocol number: 2017/01).

\section{REFERENCES}

AOAC. (1990). Official methods of analysis of the AOAC, 15th ed. Methods 932.06, 925.09, 985.29, 923.03. Association of official analytical chemists. Arlington, VA, USA.

Boirie, Y., Dangin, M., Gachon, P., Vasson, M.P., Maubois, J.L. \& Beaufrere, B. (1997). Slow and fast dietary proteins differently modulate postprandial protein accretion. Proclamations of National Academy of Sciences, 94, 14930-14935.

Campbell, T.W. (2004). Hematology of fish. In: Troy DB (ed) Veterinary hematology and clinical chemistry. Lippincott Williams \& Wilkins, Baltimore.

Cinq-Mars, D., Belanger, G., Lachance, B. \& Brisson, G.J. (1986). Performance of early weaned piglets fed diets containing various amounts of whey protein concentrate. Journal of Animal Science, 63(1), 145-150. DOI: $10.2527 /$ jas 1986.631145x

Codex Alimentarius. (2006). Standard for whey powders. Agriculture Organization of United Nations, Rome, Italy.

De Wit, J.N. (1998). Nutritional and functional characteristics of whey proteins in food products. Journal of Dairy Science, 81, 597-608. DOI: 10.3168/jds.S0022-0302(98)75613-9

Deis, R.C. (2006). The complexity of shelf life stability, 1 st. USA: Virgo pub.
Doğan, K. (2010). Turkey's Aquaculture Sector. Proc. of the 3rd Global Fisheries \& Aquaculture Research Conference. Foreign Agricultural Relations (FAR), Egypt.

Girgin Basusta, A. (2005). Balık biyolojisi araştırma yöntemleri. Nobel Yayın, Ankara, 772498.

Ha, M., Bekhit, A.E.D., McConnell, M., Mason, S. \& Carne, A. (2014). Fractionation of whey proteins from red deer (Cervus elaphus) milk and comparison with whey proteins from cow, sheep and goat milks. Small Ruminant Research, 120, $125-134$.

DOI:

10.1016/j.smallrumres.2014.04.012

Hoşsu, B., Korkut, A.Y. \& Fırat, A. (2001). Balık Besleme ve Yem Teknolojisi I. Ege Üniversitesi Su Ürünleri Fakültesi Yayınları No:50. Basımevi, Bornova, İzmir, 276s.

Hseu, J., Yeh, S., Chu, Y. \& Ting, Y. (1998). Comparison of efficacy of five anesthetics in Goldlined sea bream, Sparus sabra. Acta Zoologica Taiwanica, 9(1), 3541.

Kishawy, A.T., Amer, S.A., Osman, A., Elsayed, S.A., ElHack, M.E.A., Swelum, A.A., Ba-Awadh, H. \& Saadeldin, I.M. (2018). Impacts of supplementing growing rabbit diets with whey powder and citric acid on growth performance, nutrient digestibility, meat and bone analysis, and gut health. $A M B$ Express, 8, 86. DOI: 10.1186/s13568-018-0617-0

Mahan, D.C. (1992). Efficacy of dried whey and its lactalbumin and lactose components at two dietary lysine levels on post weaning pig performance and nitrogen balance. Journal of Animal Science,70(7), 2182-2187. DOI: 10.2527/1992.7072182x

Maswaure, S.M. \& Mandisodza, K.T. (1995). An evaluation of the performance of weaner pigs fed diets incorporating fresh sweet liquid whey. Animal Feed Science and Technology, 54, 193-201. DOI: 10.1016/0377-8401(95)00775-I

Min, S., Rumsey, T.R. \& Krochta, J. (2006). Lysozyme diffusion in smoked salmon coated with whey protein films in corporation lysozyme, CDRF.

Motalebi, A.A. \& Seyfzadeh, M. (2011). Effects of whey protein edible coating on bacterial, chemical and sensory characteristics of frozen common Kilka (Clupeonelliadelitula). Iranian Journal of Fisheries Sciences, 11(1), 132-144.

Nishanthi, M., Chandrapala, J. \& Vasiljevic, T. (2017). Compositional and structural properties of whey proteins of sweet, acid and salty whey concentrates and their respective spray dried powders. International DairyJournal, 74, 49-56. DOI: 10.1016/j.idairyj.2017.01.002

Rana, K.J., Siriwardena, S. \& Hasan, M.R. (2009). Impact of rising feed ingredient prices on aquafeeds and aquaculture production. FAO Fisheries and Aquaculture Technical Paper. No. 541. Rome, FAO.

Shahidi, F. \& Botta, J.R. (1994). Seafood's, chemistry, processing technology and quality. Chapman \& Hall London.

Yoshizawa, F. (2004). Regulation of protein synthesis by branched-chain amino acids in vivo. Biochemical and Biophysical Research Communications, 313(2), 417-422. DOI: 10.1016/j.bbrc.2003.07.013 